\title{
ERADICATION OF BRACKEN ON RAILWAY RESERVES
}

\author{
D. A. KENNEDY
}

\section{New Zealand Railways, Wellington}

Summary

Bracken (Pteridium aquilinum var esculentum) has become a serious weed problem on railway reserves adjacent to the right-of-way.

Bromacil or karbutilate at $11 \mathrm{~kg} / \mathrm{ha}$ or either of these residual herbicides at $7 \mathrm{~kg} / \mathrm{ha}$ plus ammonium sulphamate at $44 \mathrm{~kg} / \mathrm{ha}$ gave a complete kill of treated bracken.

\section{INTRODUCTION}

Bracken (Pteridium aquilinum var. esculentum) has become a major weed on the railway reserves adjacent to the right-of-way. Experiments were established on those areas principally affected to investigate the effectiveness of selected herbicides on various seasonal growth stages of bracken.

\section{EXPERIMENTAL METHOD AND TREATMENTS}

Between 1966 and 1970 approximately 40 trials were laid down in Northland, Hamilton, Wanganui, Wellington and Greymouth. Plots were $2 \times 10 \mathrm{~m}$ with application by motorised knapsack at $\frac{1}{4}$ throttle opening to give a coarse droplet pattern. Spray volume was 450 litres/ha with surfactant added at $0.05 \% \mathrm{w} / \mathrm{v}$.

The main herbicide treatments were bromacil and karbutilate applied alone and in combination with ammonium sulphamate.

A visual evaluation scale was used, initially at monthly intervals with less frequent inspections subsequently. While trials were kept under review for at least a year, a clear indication of the ultimate results was generally visible about 12 weeks after application.

\section{RESULTS AND DISCUSSION}

Assessments revealed no differences between the effects of 11 and $16 \mathrm{~kg} / \mathrm{ha}$ of either bromacil or karbutilate on initial or ultimate control. The addition of ammonium sulphamate permitted some reduction in the rate of bromacil or karbutilate; $7 \mathrm{~kg} / \mathrm{ha}$ of either in combination with $44 \mathrm{~kg} / \mathrm{ha}$ of ammonium sulphamate gave a quicker brown-off and equivalent final result as $11 \mathrm{~kg} / \mathrm{ha}$ of the residual herbicides alone.

These treatments consistently killed between 95 and $100 \%$ of the bracken when applied under optimum conditions.

Factors such as soil type, climate, stage of growth and height at time of treatment had their influence but were not as important as stage of growth; application at the fully expanded frond stage, generally during October to December, gave the best results.

\section{ACKNOWLEDGEMENTS}

Mr G. F. Bridges, Chief Civil Engineer, New Zealand Railways, Wellington. Mr W. F. Leonard, ICI, (N.Z.) Ltd., Wellington.

Proc. 28th N.Z. Weed and Pest Control Conf. 